\title{
The Correlation between the levels of HbA1c with Ureum and Creatinine in Patient with Type 2 Diabetes Mellitus
}

\author{
Tri Prasetyorini, Karningsih, Bagya Mujianto, Rus Martini \\ Medical Laboratory Technology, Health Polytechnic Jakarta III \\ Jl. Arteri JORR, Jatiwarna, Bekasi, INDONESIA \\ *Corresponding author's email: karningsihsudiro [AT] yahoo.com
}

\begin{abstract}
-
Introduction and Aims : Untransmitted diseases is the leading cause of death globally. Diabetes mellitus is one of the four priorities of untransmitted diseases. This disease is a chronic disease characterized by blood glucose levels that exceed normal values. High blood sugar levels (hyperglycemia) will cause various complications, one of which is chronic complications that can attack various organs such as eyes, kidneys, nerves and blood vessels. This study aims to find out the correlation between the results of the examination of HbAlc, urea and creatinine levels which is an indicator of complications of Chronic Kidney Failure in Type 2 DM patients.
\end{abstract}

Methods : This research is a survey research using cross-sectional study design. The respondents in this study are Type 2 DM patients who filled out the questionnaire and examined levels of HbAlc, ureum, and creatinine. Analysis of the data performed by using the SPEARMEN test SPSS for Windows 17.

Result : The result of the SPEARMEN analysis is $p=0,016(p<0.05)$ which means there is a relationship between the levels of HbAlc with age of respondent. Meanwhile, $p=0,84(p>0,05)$ which means there is no relationship between HbAlc levels of type 2 DM with urea levels of type 2 DM patients. While, there is no relationship between HbAlc levels of type 2 DM with creatinine levels of type 2 DM with $p=0.693(p>0,05)$.

Conclusions: There is a correlation between HbAlc levels of type 2 diabetes mellitus with the age of the respondent, but there is no correlation between HbAlc levels of type 2 diabetes mellitus with ureum levels of type 2 diabetes mellitus and there is no correlation between HbAlc levels with Creatinine levels of type 2 diabetes mellitus patients.

Keywords- Type 2 diabetes melittus, Ureum, Creatinine

\section{INTRODUCTION}

Data from the International Diabetes Federation (IDF) in 2014 showed that 9.1 million Indonesians were diagnosed as DM sufferers. Diabetics increased 4-fold from 108 million in the 1980s to 415 million in 2015. On 2040 it is estimated that the number will be 642 million [1]. HbA1c is an examination which is the most appropriate benchmark in DM examination. HbA1c examination is a standard in measuring glycemic levels even in non-diabetic people.

High blood sugar levels (hyperglycemia) will cause various complications, one of which is chronic complications that can attack various organs such as eyes, kidneys, nerves and blood vessels. Based on research that has been done, from $100 \mathrm{DM}$ patients who did creatinine examination, there were 61 patients who had creatinine levels above normal, 21 of them had complications, namely Chronic Kidney Failure (CKD), of which CKD was one complication that occurs in patients with Diabetes Mellitus (DM) [2].

Diabetic nephropathy is kidney damage that found in $35-45 \%$ of patients with diabetes mellitus, especially type 2 diabetes mellitus. This study aims to find out the correlation between the results of the examination of HbA1c, urea and creatinine levels which is an indicator of complications on Chronic Kidney Failure in Type 2 DM patients. 


\section{METHODS}

This is the cross-sectional study to find out the the correlation between the results of the HbA1c examination, urea and creatinine levels which is an indicator of complications on Chronic Kidney Failure in Type 2 DM patients, judging whether there is a relationship between HbA1c levels of type 2 diabetes mellitus with the age of the respondent, there is a correlation between HbA1c levels of type 2 diabetes mellitus with ureum levels of type 2 diabetes mellitus and there is a correlation between $\mathrm{HbA} 1 \mathrm{c}$ levels with creatinine level of type 2 diabetes mellitus patients.

Data retrieval is done after the respondents get a description of the research process and sign for inform consent sheet as a sign of approval.

Furthermore, the respondents have done taking the blood, let the tube sit for 15-30 until the blood is clotted, followed by a centrifuge for 15 minutes $3000 \mathrm{rpm}$. The examination was carried out by competent medical laboratory technology personnel under Dr. clinical pathology on RSUP Persahabatan. For the HbA1c examination using the Architect c4000 series, while for the examination of ureum and creatinine using the Architect ci8000 series. The data collected was analyzed by using SPSS program 17. The analysis is done using the test SPEARMEN SPSS for Windows 17.

\section{RESULTS}

\subsection{Univariat data}

This research was conducted on 68 respondents at the RSUP Persahabatan. Respondents were people with type 2 diabetes mellitus who examined HbA1c, urea, and creatinine at the same time and took data from patient questionnaires in the form of a history of type 2 diabetes mellitus, insulin use, control of type 2 diabetes mellitus and a diet program in diabetes patients mellitus type 2 . The following are the results of the study:

Tabel 1 Frequency Distribution of Type 2 Diabetes Mellitus Patients Based on Gender in RSUP Persahabatan

\begin{tabular}{lll}
\hline Gender & $\begin{array}{l}\text { Number } \\
\text { (People) }\end{array}$ & $\begin{array}{l}\text { Percentage } \\
(\boldsymbol{\%})\end{array}$ \\
\hline Male & 34 & 50 \\
\hline Female & 34 & 50 \\
\hline Total & 68 & 100 \\
\hline
\end{tabular}

Based on table 1 shows that people with type 2 diabetes mellitus have a balance between male and female as many as 34 people $(50 \%)$.

Tabel 2 Frequency Distribution of Type 2 Diabetes Mellitus Patients Based on Hereditary History in RSUP Persahabatan

\begin{tabular}{lll}
\hline Hereditary History & $\begin{array}{l}\text { Number } \\
\text { (People) }\end{array}$ & $\begin{array}{l}\text { Percentage } \\
(\boldsymbol{\%})\end{array}$ \\
\hline Yes & 38 & 55.9 \\
\hline No & 30 & 44.1 \\
\hline Total & 68 & 100 \\
\hline
\end{tabular}

Based on table 2 shows that as many as 38 people (55.9\%) people with type 2 diabetes mellitus have a history of type 2 diabetes mellitus, while 30 people $(44.1 \%)$ people with type 2 diabetes mellitus have no history of type 2 diabetes mellitus.

Tabel 3 Frequency Distribution of Type 2 Diabetes Mellitus Patients Based on the use of insulin in RSUP Persahabatan

\begin{tabular}{lll}
\hline Using insulin & $\begin{array}{l}\text { Number } \\
\text { (People) }\end{array}$ & $\begin{array}{l}\text { Percentage } \\
(\boldsymbol{\%})\end{array}$ \\
\hline Yes & 27 & 39.7 \\
\hline No & 41 & 60.3 \\
\hline Total & 68 & 100 \\
\hline
\end{tabular}

Based on table 3 shows that as many as 27 people (39.7\%) people with type 2 diabetes mellitus who using insulin, while 41 people $(60.3 \%)$ people with type 2 diabetes mellitus who did not use insulin. 
Tabel 4 Frequency Distribution of Type 2 Diabetes Mellitus Patients Based on Control in RSUP Persahabatan

\begin{tabular}{lll}
\hline Control & $\begin{array}{l}\text { Number } \\
\text { (People) }\end{array}$ & $\begin{array}{l}\text { Percentage } \\
(\boldsymbol{\%})\end{array}$ \\
\hline Yes & 65 & 95.6 \\
\hline No & 3 & 4.4 \\
\hline Total & 68 & 100 \\
\hline
\end{tabular}

Based on table 4 shows that as many as 65 people (95.6\%) people with type 2 diabetes mellitus have a control, while 3 people (4.4\%) people with type 2 diabetes mellitus have no control.

Tabel 5 Frequency Distribution of Type 2 Diabetes Mellitus Patients Based on Diet in RSUP Persahabatan

\begin{tabular}{lll}
\hline Diet & $\begin{array}{l}\text { Number } \\
\text { (People) }\end{array}$ & $\begin{array}{c}\text { Percentage } \\
(\boldsymbol{\%})\end{array}$ \\
\hline Yes & 68 & 100 \\
\hline No & 0 & 0 \\
\hline Total & 68 & 100 \\
\hline
\end{tabular}

Based on table 5 shows that as many as 68 people (100\%) people with type 2 diabetes mellitus have a diet.

\subsection{Bivariat data}

The normality of the data obtaned is tested fist to determine the correlation test used. The following results are obtained:

Tabel 6 The Result of Correlation between HbA1c levels with the age of the respondent, Ureum levels, Creatinine levels in RSUP Persahabatan.

\begin{tabular}{lll}
\hline Variabel & \multicolumn{2}{c}{ HbA1c } \\
\cline { 2 - 3 } & $\mathbf{r}$ & $\mathbf{p}$ \\
\hline $\begin{array}{l}\text { Age of the respondent } \\
(\text { sig) }\end{array}$ & -0.292 & 0.016 \\
\hline Ureum $(\mathrm{sig})$ & -0.18 & 0.884 \\
\hline Creatinin(sig) & -0.49 & 0.693 \\
\hline
\end{tabular}

The Spearman test results obtained $\mathrm{p}$ value for the HbA1c variable with the age of the respondent of $0,016<0,05$. It can be conclude that there is a correlation between the levels of diabetes mellitus type 2 HbA1c with the age of the respondent has a correlation value of -0.292 . Meanwhile, the p value for the $\mathrm{HbA}$ c variable with the ureum level is $0,884>0,05$. It can be conclude that there is no correlation between the HbA1C levels of diabetes mellitus type 2 with the ureum levels of diabetes mellitus type 2 patients. The $\mathrm{p}$ value for $\mathrm{HbAlc}$ variable with the levels of creatinin is $0,693>0,05$. It can be conclude that there is no correlation between the HbA1C levels of diabetes mellitus type 2 with the creatinine levels of diabetes mellitus type 2 patients.

\section{DISCUSSION}

Diabetes mellitus factors are divided into two, namely factors that cannot be modified and factors that can be modified [3]. Types of gender is one factor that cannot be modified. Based on the tabe 1, the number of patients with type 2 diabetes mellitus who are male and female has a balanced number, this shows that type 2 diabetes mellitus disease does not show gender differences, it can be happen to anyone who does not regulate lifestyle and eating patterns that is as many as 34 people.

Based on the table 2, 38 people with type 2 diabetes mellitus have a family history. Genes are hereditary units that are transmitted from one generation to the next and are inherited or passed down [4] Hereditary or genetic factors contribute greatly to the prevalence of type II diabetes mellitus [5]. This study, in line with research conducted by Dyah Ayu, stated that 25 people out of 30 people with type 2 diabetes mellitus have a history of type 2 diabetes mellitus.

Based on table 3, people with type 2 diabetes mellitus who did not use insulin were 41 people. Pharmacological therapy is one way to control type 2 diabetes mellitus. According to the 2015 PERKENI, phamarcological therapy consists of oral drugs and injection forms. Insulin is needed in a number of circumstances, namely $\mathrm{HbA} 1 \mathrm{c}>9 \%$, rapid weight loss, severe hyperglycemia accompanied by ketosis, severe impairment of kidney or liver function, and failure with the optimal combination of oral medication.

Monitoring for people with diabetes mellitus needs to be done. After the patient is diagnosed with diabetes, it is recommended that the patient go to the doctor at least once a month. At the time of control, it is necessary to be monitored about how to take medication, diet and physical exercise [6]. Based on table 4, people with type 2 diabetes 
mellitus who did control to the doctor were 65 people. This shows that almost all sufferers of type 2 diabetes mellitus already have an awareness of the importance of controlling physicians.

According to PERKENI 2015, the management of type 2 diabetes mellitus is divided into 4 parts, namely education, medical nutrition therapy, physical exercise, and pharmacological therapy. The principle of eating arrangements in people with type 2 diabetes mellitus is almost the same as the recommended food for the general public, which is a balanced diet and in accordance with the calorie and nutrient requirements of each individual. People with diabetes mellitus need to emphasize the importance of regular eating in terms of eating schedule, type and amount of food, especially those who use blood glucose-lowering drugs or insulin to prevent complications from type 2 diabetes mellitus [7]. Based on table 5, it was found that 68 people with diabetes mellitus use a diabetes mellitus diet or medical nutrition therapy. It can be said that sufferers of type 2 diabetes mellitus at the RSUP Persahabatan are obedient in terms of maintaining their diet. The success of the process of control of type 2 diabetes mellitus is determined by patient compliance in managing diet or daily diet [7].

Based on table $6, \mathrm{p}$ values $<0.05$ were obtained for the HbAlc variable with a creatinine level of 0.016 . This shows the correlation between HbAlc levels and the age of the respondents. Based on research conducted at the RSUP Persahabatan found that the number of respondents aged over $\geq 50$ years there were 43 people. Age is a factor that cannot be modified. This is in line with the results of previous studies that the age variable $\geq 50$ can increase the incidence of type 2 diabetes mellitus because aging causes decreased insulin sensitivity and decreased body function for glucose metabolism which causes HbA1c levels will also increase [5].

$\mathrm{HbA1c}$ is the best test to assess the risk of tissue damage caused by high blood sugar levels. HbAlc levels are stable based on the age range of erythrocytes around 100 to 120 days. Thus, HbA1c reflects average blood glucose levels over the past 2 to 3 months.

Ureum and creatinine are tests that are usually done to detect a decrease in kidney function. Ureum-creatinine is a waste product of the bodies metabolism [8].

Based on table 6, it shows the variable levels of HbAlc with ureum levels having a p value $>0.05$ which is 0.884 . These results state that there is no correlation between HbAlc levels with urea levels. Table 6 also states that there is no correlation between HbA1c levels and creatinine levels with a value of p.0.05 that is equal to 0.693. This can occur because an increase in blood sugar levels usually begins after the age of forty when the kidneys are unable to filter glucose in the long term and other chronic kidney triggers, such as hypertension, dyslipidemia, and obesity. This study is in accordance with research conducted by Arun Chutani and Sonali Pande in 2017 which states there is no correlation between $\mathrm{HbAlc}$ levels with cardar ureum and there is no correlation between $\mathrm{HbA} 1 \mathrm{c}$ levels with creatinine levels [9].

\section{CONCLUSIONS}

As the one of the treatment therapies for type 2 diabetes mellitus, insulin is widely used as a type 2 diabetes mellitus controller. After this research, data are obtained that tere are some diabetes mellitus sufferers who do not use insulin as a therapeuitc treatment. In addition to using insulin, therapies such as diet can be used as therapy in controlling type 2 diabetes mellitus, and it was found that in all diabetes mellitus patients applying the nutritional diet as a diabetes mellitus therapy step.

Increased of blood glucose levels can cause complications, which is on kidney function. Based on the research, it was found that there is a correlation between the levels of diabetes mellitus type $2 \mathrm{HbA} 1 \mathrm{c}$ with the age of the respondent, it caused by aging that occurs can reduce the work of body functions. While, the levels of diabetes mellitus type $2 \mathrm{HbA} 1 \mathrm{c}$ with the levels of ureum and creatinine showed that there is no correlation, it caused by the occurrence of chronic kidney failure is associated with the inability to filter glucose in the long term.

For sufferers of type 2 dibetes mellitus, it is advisable to do an inetory laboratory examination as well as other supporting examinations to avoid the occurrence of type 2 diabetes mellius complications. Besides based in ureum and creatinine levels, assessment of renal function complications can also be seen by examining Glomerular Filtration Rate (GFR), it is recommended to find the relationship between HbAlc levels with Glomerular Filtration Rate (GFR) and supplemented with other additional data, such as drugs consumed, lifestyle of sufferers, and diet complience in diebetes mellitus.

\section{ACKNOWLEDGEMENT}

Ethical clearance for this study was granted by Health Polytechnic Ministry of Health Jakarta III.

\section{REFERENCES}

[1] Intenational Diabetes Federation, 2017

[2] Pratiwi, Anissa, 'Gambaran Kadar Kreatinin Dalam Darah Pada Penderita Diabets Mellitus di RSUD Koja Tahun 2017’, Karya Tulis Ilmiah, Poltekkes Kemenkes Jakarta III, Bekasi, 2018. 
[3] Kementerian Kesehatan RI, 'Situasi dan Analisis Diabetes', Infodatin, 2014.

[4] Ayu, Diah, 'Hubungan Antara Pola Makan, Genetik Dan Kebiasaan Olahraga Terhadap Kejadian Diabetes Melitus Tipe Ii Di Wilayah Kerja Puskesmas Nusukan, Surakarta', Skripsi, Universiutas Muhamadiyah Surakarta, Surakarta, 2013.

[5] Sari, Melly, 'Faktor Risiko Kejadian Diabetes Melitus Tipe II Pada Masyarakat Urban Kota Semarang', Skripsi, Universitas Negeri Semarang, Semarang, 2016.

[6] Widodo, F.Y, 'Pemantauan Penderita Diabetes Mellitus', Jurnal Ilmiah Kedokteran, Volume 3 Nomor 2, 2014.

[7] Hestiana, Dita, 'Faktor-Faktor Yang Berhubungan Dengan Kepatuhan Dalam Pengelolaan Diet Pada Pasien Rawat Jalan Diabetes Mellitus Tipe 2 Di Kota Semarang', Jurnal Of Health Education, UNNES, 2017.

[8] Setyaningsih, A. Dewi. M. Imron, 'Perbedaan Kadar Ureum \& Creatinin Pada Klien Yang Menjalani Hemodialisa Dengan Hollow Fiber dan Hollow Fiber Reuse di RSUD Ungaran', Jurnal Keperawatan Medikal Bedah, Vol 1 No 1: 20, 2013.

[9] Chutani, Arun. Sonali Pande, 'Correlation of Serum Creatinine and Urea With Glycemic Index and Duration of Diabetes in Type 1 and Type 2 Diabetes Mellitus :A Comparative Study. National Journal of Physiology, Pharmacy, and Pharmacology Vol 7', 2017. 